\title{
Peningkatan Kemampuan Motorik Kasar Anak melalui Permainan Busa Geometri di Taman Kanak-kanak Sejati Ketaping Batang Anai Kab. Padang Pariaman
}

\author{
Rosnida \\ Guru Taman Kanak-kanak \\ Email : rosnida01@gmail.com
}

\begin{abstract}
Abstrak
Peningkatan kemampuan motorik kasar anak di TK Sejati Ketaping Batang Anai masih rendah, anak kurang mampu menjaga keseimbangan badan dan kekuatan kakinya, hal ini terlihat pada saat anak berjalan berjinjit dan berjalan dengan tumit, anak cepat mengatakan letih. Hal ini disebabkan kurangnya sarana permainan yang menarik bagi anak. Guru hanya memanfaatkan media yang ada, tanpa berusaha menciptakan permainan yang baru. Tujuan penelitian tindakan kelas ini adalah untuk peningkatan kemampuan motorik kasar anak melalui permainan busa geometri. Jenis penelitian adalah penelitian tindakan kelas Subjek penelitian TK Sejati Ketaping, pada kelompok B.1 dengan jumlah anak 15 orang. Teknik pengumpulan data observasi dan dokumentasi, selanjutnya diolah dengan teknik persentase. Penelitian tindakan kelas ini dilakukan dalam 2 siklus, satu lagi siklus 3 dengan satu kali pertemuan. Hasil kondisi awal pada umumnya peningkatan kemampuan motorik kasar anak masih rendah. Pada siklus I pencapaian nilai rata-rata peningkatan kemampuan motorik kasar anak meningkat tapi belum maksimal. Sedangkan pada siklus II peningkatan kemampuan motorik kasar anak sudah meningkat, tetapi belum optimal. Pada Siklus III keberhasilan pada setiap aspek ratarata tingkat keberhasilan melebihi Kriteria Ketuntasan Minimum (KKM) yang telah ditetapkan. Dengan demikian dapat disimpulkan bahwa dengan permainan dan media yang menarik sangat tepat untuk peningkatan kemampuan motorik kasar anak di TK Sejati Ketaping Batang Anai.
\end{abstract}

Kata Kunci : Permainan Busa Geometri, kemampuan motorik kasar

\section{PENDAHULUAN}

Usia dini merupakan priode emas (golden age) bagi perkembangan anak untuk memperoleh pendidikan. Priode ini adalah tahun-tahun berharga bagi seorang anak untuk mengenali berbagai macam fakta dilingkungannya sebagai stimulans terhadap perkembangan kepribadian, psikomotor, kognitif maupun sosialnya. 
Dalam UU RI No.20 Tahun 2003 tentang Sistem Pendidikan Nasional pasal 28 ayat 3 dijelaskan bahwa Taman Kanak-kanak (TK) menyelenggarakan pendidikan untuk mengembangkan kepribadian dan potensi diri sesuai dengan tahap perkembangan anak. Dijelaskan bahwa tujuan pendidikan Taman Kanak-kanak (TK) terbagi atas tiga poin yakni: (1) membantu pertumbuhan dan perkembangan jasmani, (2) mengembangkan kepribadian dan potensi diri sesuai dengan tahap perkembangan anak, (3) membantu meletakkan dasar kearah perkembangan sikap, pengetahuan, keterampilan dan daya cipta yang diperlukan oleh anak didik dalam menyesuaikan diri dengan lingkungannya dan untuk pertumbuhan serta perkembangan selanjutnya.

Kemudian dalam Surat Edaran Mendiknasmen Depdiknas No. 1839/C.C2?TU/2009, yang menerangkan tentang prinsip pendidikan Taman Kanak-kanak yaitu: "bermain sambil belajar dan belajar seraya bermain". Bermain merupakan cara terbaik untuk mengembangkan potensi anak didik. Sebelum bersekolah, bermain merupakan cara alamiah untuk menemukan lingkungan orang lain dan dirinya sendiri.

Melalui pendekaran bermain, anak-anak dapat mengembangkan aspek psikis dan fisik yang meliputi moral dan nilai-nilai agama, sosial emosional, kognitif, bahasa, fisik/motorik, kemandirian dan seni. Pada prinsipnya bermain mengandung makna menyenangkan, mengasikkan, tanpa ada paksaan dari luar diri anak, dan lebih mementingkan proses mengeksporasi potensi diri dari pada hasil akhir.

Pendekatan bermain sebagai metode pembelajaran di Taman Kanak-kanak hendaknya disesuaikan dengan perkembangan usia dan kemampuan anak didik, yaitu secara berangsur-angsur dikembangkan dari bermain sambil belajar (unsur bermain lebih dominan) menjadi belajar seraya bermain (unsur belajar mulai dominan). Dengan demikian anak didik tidak merasa canggung menghadapi pendekatan pembelajaran pada jenjang pendidikan selanjutnya dan anak dapat mengembangkan fisik motoriknya.

Perkembangan fisik yang beranjak matang maka perkembangan motorik anak sudah dapat terkoordinasi dengan baik. Setiap gerakan anak sudah selaras dengan kebutuhan atau minat anak, oleh karena itu, masa Kanak-kanak merupakan masa yang ideal untuk belajar keterampilan motorik. Masa ini ditandai dengan kelebihan gerak atau aktifasi yang cenderung menunjukkan gerakan-gerakan gesit dan lincah.

Menurut Hurlock (1993: 155) dalam buku perkembangan anak edisi keenam, menjelaskan bahwa setelah anak dapat mengendalikan gerakan tubuh secara kasar mereka siap untuk memulai keterampilan. Keterampilan tersebut didasarkan atas kematangan yang pada waktu lahir telah mengubah aktivitas acak yang ada pada saat lahir, menjadi gerakan 
terkoordinasi. Seperti contoh pada waktu kematangan otot tangan menghasilkan kemampuan menggenggam dan memegang benda, anak siap mempelajari keterampilan makan sendiri dengan menggunakan sendok. Demikian juga pada waktu kematangan otot menghasilkan kemampuan berjalan berarti anak telah siap belajar meluncur, melompat tinggi dan melompat jauh.

Sumantri (2005: 98), mengemukakan motorik kasar adalah kemampuan anak usia dini beraktivitas dengan mempergunakan otot-otot besar. Kemampuan menggunakan otot-otot besar ini bagi anak usia dini tergolong pada kemampuan gerak dasar, kemampuan ini dilakukan untuk meningkatkan kualitas hidupnya. Kesimpulannya adalah motorik kasar merupakan aktivitas yang mempergunakan oto-otot besar yang mengatur gerak dasar anak, hal ini bertujuan untuk meningkatkan kulitas hidup anak dimasa yang akan datang.

Keterampilan motorik kasar meliputi kegiatan gerak seluruh tubuh atau bagian besar tubuh. Dengan menggunakan bermacam koordinasi kelompok otot-otot tertentu anak dapat belajar untuk merangkak, melempar dan meloncat. Koordinasi keseimbangan, ketangkasan kelenturan, kekuatan, kecepatan, dan ketahanan merupakan motorik kasar anak (dalam Moeslichatoen (1999:16)).

Menurut Suyanto (2005:51), perkembangan motorik meliputi perkembangan otot kasar dan otot halus. Otot kasar atau otot besar ialah otot-otot badan yang tersusun oleh otot-otot lurik. Otot ini berfungsi untuk melakukan gerakan dasar tubuh yang terkoordinasi oleh otak, seperti berjalan, berlari, melompat, menendang, melempar, memukul, mendorong dan menarik. Oleh karena itu gerakan tersebut disebut gerakan dasar.

Dari beberapa pendapat dapat disimpulkan motorik kasar merupakan aktivitas yang mempergunakan oto-otot besar yang mengatur gerak dasar anak. Gerakkannya membutuhkan kemampuan koordinasi sebagian besar bagian tubuh anak, untuk meningkatkan kulitas hidup anak dimasa yang akan datang.

Seorang anak dapat dikatakan memiliki kemampuan motorik kasar menurut Depdiknas (2007:5), karakteristik perkembangan motorik anak adalah antara lain: 1) Berdiri di atas satu kaki selama 5- 10 detik, 2) Menaiki dan menuruni tangga dengan berpegangan tangan dan bergantian, 3) Berjalan pada garis lurus, 4) Berjalan dengan jinjit sejauh 3 meter, 4) Berjalan mundur dan melompar di tempat, 5) Melompat ke depan dengan 2 kaki sebanyak 4 kali, 6) Bermain dengan bola (menendangb dengan mengayunkan kaki kebelakang dan ke depan, menangkap bola yang melanmbung dengan menangkapnya ke dada dan mendorong), 7)Menarik dan mengendarai sepeda roda tiga atau mainan 
beroda lainnya dan 8) Melakukan permainan dengan ketangkasan dan kelincahan seperti menggunakan papan luncur.

Sedangkan menurut Sujiono (2008: 1.16) mengatakan bahwa karakteristik perkembangan motorik kasar anak Taman Kanak-kanak adalah sebagai berikut : 1) Berlari dan langsung menendang bola, 2) Melompat-lompat dengan kaki bergantian, 3) Melambungkan bola tenis dengan satu tangan dan menangkapnya dengan dua tangan, 4) Berjalan pada garis yang ditentukan, 5) Berjinjit dengan tangan dipinggul, 6) Menyentuh jari kaki tanpa menekuk lutut, dan 6) Mengayunkan satu kaki ke depan atau kebelakang tanmpa kehilangan keseimbangan

Menurut pendapat di atas ada beberapa kemampuan-kemampuan yang dapat dilakukan dan dicapai oleh anak sesuai dengan perkembangan dan petumbuhan dan juga rangsangan yang diterimamnya. Oleh sebab itu, pendidikan di Taman Kanak-kanak, harus dapat memberikan bimbingan yang tepat agar anak dapat melalui tahaptahap perkembangan tersebut.

Perkembangan motorik mengarah pada perkembangan pengendalian gerakan melalui kegiatan pusat syaraf, urat syaraf, dan otot yang terkoordinasi (Hurlock, 1999: 150). Lebih lanjut Hurlock menyebutkan bahwa sebagian tugas perkembangan anak yang paling penting dalam masa TK dan dalam tahun-tahun permulaan sekolah, terdiri atas perkembangan motorik yang didasarkan atas penggunaan kumpulan otot yang berbeda secara terkoordinasi (1999: 150). Pada tahap belajar awal, kurangnya koordinasi pusat syaraf, urat syaraf, dan otot, sehingga anak masih banyak melakukan kesalahan dan kurang cermat dalam gerakan.

Perkembangan keterampilan motorik merupakan faktor yang sangat penting bagi perkembangan pribadi secara keseluruhan. Hurlock dalam Yusuf (2001: 105) mengemukakan beberapa alasan mengenai fungsi perkembangan motorik bagi perkembangan individu, yaitu: 1) Melalui keterampilan motorik, anak dapat menghibur dirinya dan memperoleh perasaan senang, seperti anak merasa senang dengan memiliki keterampilan memainkan boneka, melempar, dan berlari. 2) Melalui keterampilan motorik, anak dapat beranjak dari kondisi "helplessness" (tidak berdaya) pada bulan-bulan pertama dalam kehidupannya ke kondisi yang "independence" (bebas, tidak bergantung). Kondisi ini akan menunjang perkembangan "self confidence" (rasa percaya diri). 3) Melalui keterampilan motorik, anak dapat menyesuaikan dirinya dengan lingkunag sekolah, pada usia pra-sekolah (Taman Kanakkanak), atau usia kelas-kelas awal sekolah dasar, anak sudah dapat dilatih, menulis menggambar, melukis, dan baris-berbaris. 4) Melalui perkembangan motorik yang normal memungkinkan anak dapat bermain 
atau bergaul dengan teman sebayanya, sedangkan yang tidak normal, menghambat anak untuk dapat bergaul dan bermain dengan anak sebayanya, atau dia akan dikucilkan atau anak yang terpinggirkan. Dan 5) Perkembangan keterampilan anak sangat penting bagi perkembangan "self" concept" atau kepribadian anak.

Sedangkan menurut Cureton dalam Gusril (2009: 98) mengatakan fungsi utama kemampuan motorik adalah untuk mengembangka kesanggupan dan kemampuan setiap individu yang berguna untiuk mempertinggi daya kerja.

Kemampuan motorik dapat dikembangkan melalui permainan. Hal itu dikarenakan permainan adalah hal yang paling disenangi oleh anak. Salah satu permainan yang dapat mengembangkan kemampuan motorik kasar anak adalah permainan busa geometri. Permainan busa geometri adalah permainan modifikasi yang terinspirasi dari busa geometri. Busa geometri dibuat dari bahan dasar busa yang berbentuk geometri. Dengan ini peneliti memberi nama permainan adalah busa geometri.

Permainan "busa geometri" adalah bentuk-bentuk dasar geometri seperti segitiga, persegi, persegi panjang dan lingkaran yang berbahan dasar busa, digunakan untuk latihan target anak-anak akan mendarat dari lompatannya. Permainan busa geometri yang dimainkan oleh anak diharapkan mampu meningkatkan imajinasi dan kreativitas anak dalam meningkatkan kekuatan fisik, kelincahan dan ketangkasan. Menurut Kamtini (2005:61) "alat permainan yang optimal adalah alat permainan yang mampu meransang dan menarik minat anak, sekaligus mampu mengembangkan berbagai jenis kemampuan anak dan tidak membatasinya pada satu aktivitas tertentu saja".

\section{METODE PENELITIAN}

Jenis penelitian ini adalah penelitian tindakan kelas (Classroom Action Research). Menurut Aqib (2006:13), penelitian tindakan kelas merupakan suatu pencermatan terhadap kegiatan yang sengaja dimunculkan, dan terjadi di dalam kelas. Sedangkan Arikunto (2009:104) menjelaskan "penelitian tindakan sebagai bentuk investigasi yang bersifat reflektif partisipasif, kolaboratif dan spiral yang memiliki tujuan untuk melakukan perbaikan sistem, metode kerja, proses, isi, kompetensi dan situasi".

Subjek dalam penelitian ini adalah anak-anak TK Sejati Ketaping Kecamatan Batang Anai Kabupaten Padang Pariaman pada kelompok B1. Jumlah anak seluruhnya adalah 15 orang, yang terdiri dari 8 orang anak perempuan dan 7 orang anak laki-laki. Teknik dalam pengumpulan data yang digunakan adalah teknik observasi dan dokumentasi. 


\section{HASIL}

Kondisi awal sebelum penelitian dilaksanakan terlebih dahulu peneliti melakukan observasi tentang kemampuan motorik kasar anak dalam berjalan di Taman Kanak-kanak Sejati Ketaping Padang Pariaman khususnya dikelompok B1. Peneliti melihat bahwa kemampuan motorik kasar anak dalam berjalan pada garis lurus masih rendah, hal ini dapat dilihat dari sebagian besar anak mengalami kesulitan dalam kegiatan pembelajaran motorik kasar anak dalam berjalan pada garis lurus melalui garis keramik, terutama dalam berjalan berjinjit dan berjalan dengan tumit.

Untuk lebih jelasnya kondisi awal kemampuan motorik kasar anak dalam berjalan pada kelompok B1 di Taman Kanak-kanak Sejati Ketaping Padang Pariaman dapat dilihat pada tabel berikut ini:

Tabel 1: Hasil Observasi Kemampuan Motorik Kasar Anak Pada Kondisi Awal (Sebelum Tindakan)

\begin{tabular}{|l|l|c|c|c|c|c|c|}
\hline \multirow{2}{*}{ No } & \multirow{2}{*}{ Aspek yang di nilai } & \multicolumn{6}{|c|}{ Nilai } \\
\cline { 3 - 8 } & & \multicolumn{2}{|c|}{ ST } & \multicolumn{2}{|c|}{ T } & \multicolumn{2}{|c|}{ R } \\
\cline { 3 - 8 } & f & $\%$ & f & $\%$ & F & $\%$ \\
\hline 1 & $\begin{array}{l}\text { Anak mampu berjalan pada } \\
\text { garis lurus sejauh 3-4 m }\end{array}$ & 2 & 13 & 2 & 13 & 11 & 74 \\
\hline 2 & $\begin{array}{l}\text { Anak mampu berjalan } \\
\text { berjinjit sejauh 2-3 meter }\end{array}$ & 1 & 6.6 & 1 & 6.6 & 13 & 86.6 \\
\hline 3 & $\begin{array}{l}\text { Anak mampu berjalan } \\
\text { dengan tumit sejauh 2-3 } \\
\text { meter }\end{array}$ & 1 & 6.6 & 1 & 6.6 & 13 & 86.6 \\
\hline 4 & $\begin{array}{l}\text { Anak mampu berjalan } \\
\text { dengan tumit sambil } \\
\text { membawa beban }\end{array}$ & 1 & 6.6 & 2 & 13 & 12 & 80 \\
\hline Nilai rata-rata & 1 & 8 & 1.5 & 9.8 & 12 & 81.8 \\
\hline
\end{tabular}

Berdasarkan tabel di atas, kemampuan motorik kasar anak sebelum tindakan masih sangat rendah, hal ini dapat dilihat dari ke 4 aspek. Anak mampu berjalan pada garis lurus sejauh 3-4 meter, berjalan dengan tumit sejauh 2-3 meter, berjalan berjinjit sejauh 2-3 meter dan berjalan dengan tumit sambil membawa beban. Oleh karena itu perlu dilakukan penelitian untuk meningkatkan ke 4 aspek tersebut.

Pada siklus I didapat hasil kemampuan motorik kasar anak sudah mulai meningkat. Hal itu dapat dilihat pada tabel berikut :

Tabel 2: Hasil Observasi Peningkatan Kemampuan motorik Kasar Anak Melalui Busa Geometri Pada Siklus I

\begin{tabular}{|l|l|l|}
\hline No & Aspek yang di nilai & Nilai \\
\hline
\end{tabular}




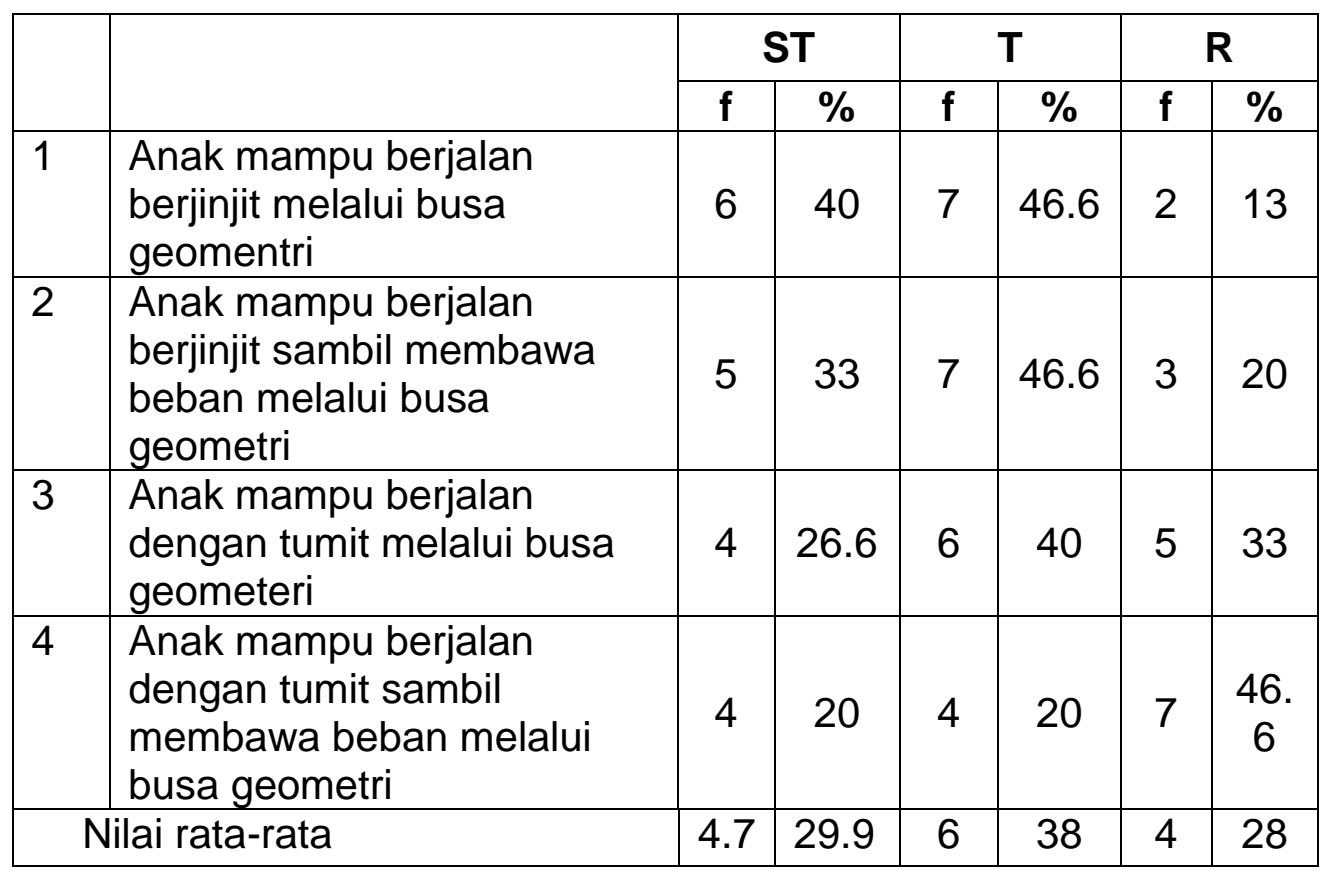

Berdasarkan tabel 2 di atas dapat dilihat kemampuan motorik kasar anak dalam berjalan pada siklus 1 pertemuan 3 yaitu: Aspek 1 Anak mampu berjalan berjinjit melalui busa geomentri, anak memperoleh nilai sangat tinggi berjumlah 6 dengan persentase 40\%, anak yang memperoleh nilai tinggi berjumlah 7 orang dengan persentase $46.6 \%$, dan anak yang memperoleh nilai rendah berjumlah 2 dengan persentase $13 \%$.

Aspek 2 Anak mampu berjalan berjinjit sambil membawa beban melalui busa geometri, anak yang memperoleh nilai sangat tinggi berjumlah 5 orang dengan persentase $33 \%$, anak yang memperoleh nilai tinggi 7 orang dengan persentase $46.6 \%$, dan anak yang memperoleh nilai rendah 3 orang dengan persentase $20 \%$.

Aspek 3 Anak mampu berjalan dengan tumit melalui busa geometeri melalui busa geometri, anak yang memperoleh nilai sangat tinggi 4 orang dengan persentase $26.6 \%$, anak yang memperoleh nilai tinggi 6 orang dengan persentase $40 \%$, dan anak yang memperoleh nilai rendah 5 orang dengan persentase $33 \%$.

Aspek 4 Anak mampu berjalan dengan tumit sambil membawa beban melalui busa geometri, anak yang memperoleh nilai sangat tinggi 4 orang dengan persentase $26.6 \%$, anak yang memperoleh nilai tinggi 4 orang dengan persentase $26.6 \%$, dan anak yang memperoleh nilai rendah 7 orang dengan persentase $46.6 \%$.

Pada siklus I peningkatan kemampuan motorik kasar anak di TK Sejati Ketaping batang Anai masih rendah. Hal ini terlihat dari sebagian besar anak belum termotivasi untuk berjalan berjinjit dan berjalan dengan tunit melalui busa geometri. Pelaksanaan pembelajaran pada siklus I 
sudah sesuai dengan rencana, berdasarkan hasil pengamatan dampak pembelajaran belum cukup berhasil, maka peneliti melanjutkan pada siklus II dan melakukan perubahan sebagai berikut: merubah tema dan sub tema, menambah waktu pelaksanaan menambah beban.

Peningkatan kemampuan motorik kasar anak dalam berjalan melalui busa geometri pada siklus II pertemuan 3 dapat dilihat pada tabel 13 di bawah ini.

Tabel 3: Hasil Observasi Peningkatan Kemampuan Motorik Kasar Melalui Busa geometri Pada Siklus II Pertemuan 3

\begin{tabular}{|l|l|c|c|c|c|c|c|}
\hline \multirow{2}{*}{ No } & \multirow{2}{*}{ Aspek yang di nilai } & \multicolumn{5}{|c|}{ Nilai } \\
\cline { 3 - 7 } & & \multicolumn{2}{|c|}{ ST } & \multicolumn{2}{|c|}{ T } & \multicolumn{2}{|c|}{ R } \\
\cline { 3 - 8 } & & f & $\%$ & f & $\%$ & f & $\%$ \\
\hline 1 & $\begin{array}{l}\text { Anak mampu berjalan berjinjit } \\
\text { melalui busa geomentri melalui } \\
\text { busa geometri }\end{array}$ & 14 & 93 & 1 & 6.6 & - & - \\
\hline 2 & $\begin{array}{l}\text { Anak mampu berjalan berjinjit } \\
\text { sambil membawa beban } \\
\text { melalui busa geometri }\end{array}$ & 13 & 73 & 2 & 13 & - & - \\
\hline 3 & $\begin{array}{l}\text { Anak mampu berjalan dengan } \\
\text { tumit melalui busa geometeri }\end{array}$ & 14 & 93 & 1 & 6,6 & - & - \\
\hline 4 & $\begin{array}{l}\text { Anak mampu berjalan dengan } \\
\text { tumit sambil membawa beban } \\
\text { melalui busa geometri }\end{array}$ & 10 & 66.6 & 4 & 26.6 & 1 & 6.6 \\
\hline Nilai Rata-rata & 10.7 & 81.5 & 2 & 13 & 1 & 6.6 \\
\hline
\end{tabular}

Berdasarkan tabel 3 di atas dapat dilihat kemampuan motorik kasar anak dalam berjalan melalui busa geometri pada siklus II pertemuan 3 yaitu: Aspek 1 Anak mampu berjalan berjinjit melalui busa geomentri, 14 orang anak memperoleh nilai sangat tinggi dengan persentase 93\%, 1 orang anak memperoleh nilai tinggi dengan persentase $6.6 \%$, dan tidak ada anak yang memperoleh nilai rendah.

Aspek 2 Anak mampu berjalan berjinjit sambil membawa beban melalui busa geometri, yang bernilai sangat tinggi 13 orang dengan persentase $86.6 \%$, bernilai tinggi 2 orang dengan persentase $13 \%$, dan anak yang bernilai rendah sudah tidak ada lagi.

Aspek 3 anak mampu berjalan dengan tumit melalui busa geometri, anak yang memperoleh nilai sangat tinggi 12 orang dengan persentase $80 \%$, bernilai tinggi tinggi 3 orang dengan persentase $20 \%$, dan anak yang bernilai rendah sudah tidak ada lagi

Aspek 4 Anak mampu berjalan sambil berjinjit sambil membawa beban melalui busa geometri yang bernilai sangat tinggi 10 orang dengan 
persentase $66.6 \%$, bernilai tinggi 4 orang dengan persentase $26.6 \%$, dan 1 anak yang bernilai rendah dengan persentase $6.6 \%$.

Pada siklus II peneliti menemukan pembelajaran yang dilakukan melalui permainan busa geometri mengalami peningkatan proses dan hasil belajar. Dari pencapaian pada siklus I dan II, peneliti yakin bahwa permainan busa geometri dapat meningkatakan kemampuan motorik kasar anak di TK Sejati Ketaping Batang Anai. Dengan hasil ketercapaian dari aspek 1 anak mampu berjalan berjinjit melalui busa geometri mencapai 14 orang dengan persentase 93\%. Pada aspek 2 anak berjalan berjinjit sambil membawa beban melalui busa geometri mencapai hasil 13 orang dengan persentase $86.6 \%$. Pada aspek 3 anak mampu berjalan dengan tumit melalui busa geometri mencapai hasil 12 orang dengan persentase $80 \%$. Pada aspek 4 anak mampu berjalan dengan tumit sambil membawa beban dengan ketercapaian hasil 10 orang dengan persentase $66.6 \%$. Pada aspek ke 4 ini belum mencapain Kriteria ketuntasan Minimum (KKM), maka peneliti melanjutkan pada siklus III

Dari uraian di atas terlihat bahwa pada aspek ke 4 peningkatan kemampuan motorik kasar anak belum mencapai Kriteria Ketuntasan Minimum yaitu 75\%, sementara hasil yang ddiperoleh baru mencapai $66.6 \%$. Untuk itu peneliti melanjutkan pada pada siklus III dengan satu kali pertamuan. Siklus III dilaksanakan sebanyak 1 kali pertemuan, terdiri dari rencana tindakan, pelaksanaan dan observasi.

Tabel 4: Hasil Observasi Peningkatan Kemampuan Motorik Kasar Anak Melalui Permainan Busa Geometri Pada Siklus III Pertemuan I

\begin{tabular}{|c|l|c|c|c|c|c|c|}
\hline \multirow{2}{*}{ No } & \multicolumn{2}{|c|}{ Aspek yang dinilai } & \multicolumn{6}{|c|}{ Nilai } \\
\cline { 3 - 8 } & & \multicolumn{2}{|c|}{ ST } & \multicolumn{2}{|c|}{ T } & f & f \\
\hline 1 & $\begin{array}{l}\text { Anak mampu berjalan } \\
\text { berjinjit melalui busa } \\
\text { geometri }\end{array}$ & 14 & 93 & 1 & 6.6 & - & - \\
\hline 2 & $\begin{array}{l}\text { Anak mampu berjalan } \\
\text { berjinjit sambil membawa } \\
\text { beban melalui busa } \\
\text { geometri }\end{array}$ & 14 & 93 & 1 & 6.6 & - & - \\
\hline 3 & $\begin{array}{l}\text { Anak mampu berjalan } \\
\text { dengan tumit melalui busa } \\
\text { geometri }\end{array}$ & 14 & 93 & 1 & 6.6 & - & - \\
\hline 4 & $\begin{array}{l}\text { Anak mampu berjalan } \\
\text { dengan tumit sambil } \\
\text { membawa beban melalui } \\
\text { busa geometri }\end{array}$ & 13 & 86.6 & 1 & 6.6 & 1 & 6.6 \\
\hline$\quad$ & & & & & & \\
\hline
\end{tabular}


Berdasarkan tabel di atas peningkatan kemampuan motorik kasar anak pada: Aspek 1: Anak mampu berjalan berjinjit melalui busa geometri, anak yang memperoleh nilai berjumlah 14 orang dengan persentase 93\%, anak yang memperolehnilai tinggi berjumlah 1 orang dengan persentase $6.6 \%$ dan yang memperoleh nilai rendah sudah tidak ada lagi

Aspek 2: Anak mampu berjalan berjinjit sambil membawa beban melalui busa geometri, anak yang memperoleh nilai sangat tinggi berjumlah 14 orang dengan persentase 93\%, anak yang memperoleh nilai tinggi berjumlah 1 orang dengan persentase $6.6 \%$ dan anak yang memperoleh nilai rendah sudah tidak ada lagi

Aspek 3 : Anak mampu berjalan dengan tumit melalui busa geometri, anak yang memperoleh nilai sangat tinggi berjumlah 14 orang, anak yang memperoleh nilai tinggi berjumlah 1 orang dengan persentase $6.6 \%$ dan anak yang memperoleh nilai rendah sudah tidak ada lagi

Aspek 4 : Anak mampu berjalan dengan tumit sambil membawa beban melalui busa geometri, anak yang memperoleh nilai sangat tinggi berjumlah 13 orang dengan persentase $86.6 \%$ dan anak yang memperoleh nilai tinggi berjumlah 1 orang dengan persentase $6.6 \%$ dan anak yang memperoleh nilai rendah berjumlah 1 orang dengan persentase 6.6

\section{PEMBAHASAN}

Pada kondisi awal kemampuan motorik kasar anak terlihat masih rendah berkembang. Anak belum mampu berjalan berjinjit dan berjalan dengan tumit mengikuti garis lurus. Pada kondisi awal ini dengan nilai rata-rata pada kategori kategori sangat tinggi 1.5\%. Kemudian peneliti melakukan siklus I dengan kegiatan, anak berjalan berjalan berjinjit dan berjalan dengan tumit melalui busa geometri.

Menurut Sujiono (2008:4.7) mengatakan "Berjalan dapat diartikan sebagai perpidahan berat badan dari satu kaki ke kaki yang lain dengan salah satu kaki tetap kontak dengan tempat bertumpunya sepanjang kegiatan itu berlangsung. Berjalan merupakan kegiatan yang paling banyak digunakan maupun sebagai keterampilan dasar setiap individu. Berjalan dapat dilakukan dengan berbagai variasi, seperti berjalan berjinjit dan berjalan dengan tumit.

Berarti dengan menggunakan busa geometri dapat meningkatkan kegiatan anak berjalan berjinjit dan berjalan dengan tumit. Hal ini terlihat hasil siklus I ternyata terjadi peningkatan kegiatan berjinjit dan berjalan dengan tumit anak dengan persentase nilai rata-rata sangat tinggi dari kondisi awal $1.5 \%$ menjadi $29 \%$, namu belum mencapai Kriteria 
Ketuntasan Minimum yang ditetapkan, maka peneliti melanjutkan pada siklus ke II

Pada siklus II anak lebih bersemangat melakukan berjalan berjinjit dan berjalan dengan tumit melalui busa geometri. Maka peneliti memvariasikan media dengan menambah beban, seperti mangkok pakai buku atau majalah. Anakpun antusias mengikuti kegiatan berjalan berjinjit dan berjalan dengan tumit melalui busa geometri terjadinya peningkatan signifikan siklus I rata-rata sangat dengan persentase $29 \%$ menjadi $84.2 \%$

Menurut Briggs (2014:16) media pembelajaran adalah sarana fisik untuk menyampaikan isi/materi pembelajaran. Sedangkan menurut National Education Association (NEA) (2014:16) mengungkapkan "media pembelajaran adalah sarana komunikasi dalam bentuk cetak, maupun pandang, dengar, termasuk teknologi perangkat keras.

Berdasarkan pendapat di atas dapat disimpulkan bahwa media adalah segala sesuatu yang dapat digunakan untuk menyalurkan pesan dari sipengirim kepada penerima sehingga dapat merangsang pikiran, perasaan, minat, serta perhatian anak sedemikian rupa sehingga proses belajar terjadi.

Pada siklus II peneliti menambah media beban yang dibawa anak, hasil yang dicapai rata-rata nilai sangat tinggi $84.2 \%$. Karena pada siklus II aspek ke 4 masih belum mencapai Kriteria Ketuntasan Minimum (KKM), maka peneliti melanjutkan pada siklus III.

Pada siklus III peneliti memberikan motivasi, dorongan supaya anak lebih bersemangat dalam melakukan kegiatan berjalan berjinjit dan berjalan dengan tumit.

Menurut Sudirman (2014:16) motivasi adalah "sebagai daya upaya yang mendorong sesorang untuk melakukan sesuatu". Sedangkan menurut Azwar (2014:16) motivasi adalah "rangsangan, dorongan ataupun pembengkit tenaga yang dimiliki seseorang untuk melakukan sesuatu.

Berdasarkan pendapat di atas, peningkatan kemampuan motorik kasar anak dalam berjalan berjinjit dan berjalan dengan tumit dengan menggunakan busa geometri, dengan memberikan motivasi yang lebih banyak kepada anak. Melalui motivasi anak lebih bersemangat untuk melakukan kegiatan.

Berdasarkan keterangan di atas, terjadi peningkatan kemampuan motorik kasar anak dalam berjalan berjinjit dan berjalan dengan tumit melalui busa geometri pada kelompok B.1 TK Sejati Ketaping Padang Pariaman dari siklus II dengan nilai rata-rata $84.2 \%$ meningkat menjadi 93\%. Ini menunjukkan bahwa busa geometri dapat meningkatkan 
kemampuan motorik kasar anak. Hasil pada siklus III sudah melebihi criteria Ketuntasan Minimum (KKM). Maka penelitian diberhentikan pada siklus III ini.

\section{SIMPULAN}

Penerapan busa geometri dapat meningkatkan kemampuan motorik kasar anak dalam berjalan di Taman Kanak-kanak Sejati Ketaping Padang Pariaman. Implikasi dalam penelitian ini adalah busa geometri dapat dijadikan salah satu bentuk permainan untuk meningkatkan kemampuan motorik kasar anak dalam berjalan, baik dilakukan oleh guru di sekolah maupun oleh orangtua di rumah. Busa geometri telah menerapkan kegiatan bermain sambil belajar dan belajar seraya bermain sehingga anak tidak merasa terbebani untuk belajar. Pembelajaran yang disajikan dalam bentuk permainan yang menyenangkan akan menarik bagi anak.

Penerapan penelitian yang dilakukan adalah peneliti merancang pembelajaran untuk meningkatkan motorik kasar anak dalam berjalan. Busa geometri dapat dilakukan semua anak, yang mana anak melakukan berlajan dengan tumit dan berjinjit dengan busa geometri, melakukan jalan ditempat, melakukan busa geometri di dalam kelas dan melakukan busa geometri di kelas. Berdasarkan hasil penelitian dan tinjauan kajian teori maka implikasi penelitian ini adalah:

1. Selama ini busa geometri dipergunakan untuk mengembangkan kemampuan motorik kasar anak dalam berjalan. Namun setelah penelitian, ditemukan bahwa busa geometri dapat meningkatkan kemampuan motorik kasar anak dalam berjalan.

2. Aplikasi busa geometri ini mudah guru dalam mengembangkan pembelajaran motorik kasar anak dalam berjalan pada anak karena dapat menarik dan memudahkan guru dalam mengembangkan kemampuan motorik kasar anak dalam berjalan.

\section{DAFTAR PUSTAKA}

Aisyah, Siti. 2009. Pembelajaran Terpadu. Jakarta: Universitas Terbuka.

Arikunto, Suharsimi. 2012. Penelitian Tindakan Kelas. Jakarta: Bumi Aksara.

2009. Prosedur Penelitian, Suatu Pendekatan Praktik. Jakarta : PT Rineka Cipta

Aqib, Zainal. 2006. Penelitian Tindakan Kelas Untuk Guru. Bandung: Irama Widya.

Departemen Pendidikan Nasional, 2007. Pengembangan Kemampuan Motorik Kasar di Taman Kanak-kanak. Jakarta 
Hidalyani, Rini, dkk. 2009. Psikologi Perkembangan Anak. Universitas Terbuka. Jakarta

Hurlock, Elizabeth. 1999. Perkembangan Anak Jilid 1 Edisi ke Enam. Jakarta: Erlangga.

Jamaris, Martini. 2003. Perkembangan dan Pengembangan Anak Usia Taman Kanak-kanak., Jakarta: Universitas Negeri Jakarta. , 2006. Perkembangan dan Pengembangan Anak Usia Taman Kanak-kanak, Jakarta: Grasindo.

Kementerian Pendidikan Nasional. 2010. Kurikulum Taman Kanak-kanak. Jakarta: Dirjen Pendidikan Dasar dan Menengah.

Kunandar. 2008. Langkah Mudah Penelitian Kelas sebagai Pengembangan Profesi Guru. Jakarta : Rajawali Pers.

Moeslichatoen. 1999. Metode Pengajaran di Taman Kanak-kanak, Jakarta : PT Rineka Cipta.

Sudono, Anggani. 2000. Sumber Belajar dan Alat Permainan untuk Pendidikan Anak Usia Dini. Jakarta: Grasindo

Sugiyono. 2006. Metode Penelitian Kuantitatif, kualitatif dan $R \& D$. Bandung: Alfabeta.

Sujiono, Bambang. 2008. Metode Pengembangan Fisik. Jakarta: Universitas Terbuka.

Sumantri. 2005. Model Pengembangan Keterampilan Motorik Anak Usia Dini. Jakarta: Depdiknas Dikt .

Sutanto, Ahmad. 2011. Perkembangan Anak Usia Dini: Pengantar dalam Berbagai Aspeknya. Jakarta: Kencana.

Surat Edaran Mendiknasmen Depsiknas No. 1830/C.C2.CU/2009

Suyanto, Slamet. 2005. Konsep Dasar Pendidikan Anak Usia Dini. Jakarta: Depdiknas Dikti

Undang-Undang No. 20 Tahun 2003. Tentang Sistem Pendidikan Nasional. Jakarta: Kencana Pranada Media Group

Zulkifli. 2006. Psikologi Perkembangan. Bandung: Remaja Rosda http://azwar.blogspot.com/2014/03/pendidikan-ideal-yang-sesuaidengan.html 